\title{
Osmotic Dehydrofreezing for Protection of Rheological Properties of Agricultural Products
}

\section{from Freezing-Injury}

\author{
Shigehiko OHNISHI $^{1 *}$ and Osato MIYAWAKI ${ }^{2}$ \\ ${ }^{1}$ Fermentation and Food Research Institute, Kagawa Prefectural Industrial Technology Center, 1351-1 Noma, Uchinomi, Kagawa \\ 761-4421, Japan \\ ${ }^{2}$ Department of Applied Biological Chemistry, The University of Tokyo, 1-1-1 Yayoi, Bunkyo-ku, Tokyo 113-8657, Japan
}

Received September 28, 2004; Accepted January 5, 2005

\begin{abstract}
Three agricultural products, carrot, broccoli and potato tissue, were osmotically dehydrated by immersion in $50 \%(\mathrm{w} / \mathrm{w})$ sucrose solution and their rheological properties were measured before and after freezing-thawing-rehydration. Although the dynamic elasticity and viscosity became smaller after freezing-thawing as compared to the fresh sample, the osmotically dehydrated sample showed much higher retention of rheological properties than the untreated sample with the exception of the potato sample. In measurement of complex impedance, the radius of the Cole-Cole arc, an index of the intactness of cell plasma membrane, showed good correlations with the rheological properties for carrot and broccoli. The amount of drip from the cell tissue was also compared among various treatments. The osmotically dehydrated sample showed much less drip than the untreated sample after freezing-thawing-rehydration. Under an optical microscope, the cell structure seemed to show less injury for the osmotically dehydrated sample than the untreated sample. These results indicate that osmotic dehydrofreezing protects the cell structure, in particular the cell plasma membrane, against freezing in jury to give reduced softening after freezing-thawing.
\end{abstract}

Keywords: osmotic dehydrofreezing, agricultural products, freezing injury

\section{Introduction}

Freezing has been shown as the most suitable method for preserving sensory attributes, such as color and flavor, as well as the nutritional value of agricultural products. Freezing, however, can cause texture degradation by freezing injury of cell tissue. The rheological properties of agricultural products reflect the turgor pressure (Virgin, 1955), which is very sensitive to the state of the plasma membrane in cell tissue. Plasma membrane is considered to be the primary site of freezing injury because of its weak structure (Burke et al., 1976; Steponkus, 1984; Webb et al., 1994; Dejmek et al., 2002). On the other hand, the state of the cell wall is also known to affect the rheological properties of agricultural products after freezing-thawing (Ohnishi et al., 2002). We previously reported that the loss of turgor pressure by plasma membrane injury is the major cause of softening after freezingthawing, while injuries to the cell wall and intercellular structure play an auxiliary role to the change in rheological properties (Ohnishi et al., 2003). Thus, alleviation of plasma membrane injury during freezing is important for prevention of tissue softening after thawing.

Dehydration of water in cell structure may reduce the membrane injury by decreasing the freezable water content. Air-drying is one common dehydration procedure and has been well studied as a pretreatment of frozen vegetables (Howard and Campbell, 1946; Lazar et al., 1961;

E-mail: ohnishi@itc.pref.kagawa.jp
Talburt and Legault 1950; Talburt et al., 1950). These studies, however, pay no attention to affect of the process to the cell plasma membrane. Forni et al. (1990) have reported that air-dehydration, even when conducted at low temperature, causes quality deterioration such as a change of color and softening of texture because of membrane injury during the drying process.

Osmotic dehydration is widely used for the partial removal of water from vegetables and fruits by immersion in osmotic solution. Osmotic dehydration is an effective method for reducing food water content with minimal damage to the cell structure of agricultural products because it is conducted at a lower temperature $\left(\sim 30^{\circ} \mathrm{C}\right)$ than air-drying $\left(60 \sim 80^{\circ} \mathrm{C}\right)$ (Kamewada et al., 1997). Osmotic dehydration has been also reported to reduce deterioration by freezing injury allowing improvements in the quality of frozen agricultural products such as apples (Lazar et al., 1961; Ponting et al., 1966; Tregunno and Goff, 1996), strawberries (Garrote and Bertone, 1989), kiwi fruits (Talens et al.; 2003), tropical fruits (Moy et al., 1978; Moyano et al., 2002), pears (Bolin and Huxsoll, 1993), carrots and green beans (Biswal et al., 1991). The effect of osmotic dehydration, however, has not been studied from the viewpoint of cell plasma membrane injury by freezing-thawing.

In this research, we osmotically dehydrated agricultural products by immersion in a high concentration sugar solution and measured their rheological properties before and after freezing-thawing-rehydration. We also investi- 
gated the protective effect of osmotic dehydrofreezing for tissue softening caused by freezing injury.

\section{Materials and Methods}

Agricultural products The agricultural products carrot, broccoli and potato, were obtained from a local market. Cylindrical samples $(6.9 \mathrm{~mm}$ in diameter, $35 \mathrm{~mm}$ in length) were prepared with a cork borer $(7.0 \mathrm{~mm}$ inner diameter).

Osmotic dehydration and rehydration Sample tissues were immersed in a beaker containing 1,000 $\mathrm{ml}$ of $50 \%$ (w/ w) sucrose solution at $10^{\circ} \mathrm{C}$ for 5 hours. The solution was stirred with a magnetic stirrer. Samples were then removed from solution, soaked in $0.9 \% \mathrm{NaCl}$ (Nacalai Tesque, Inc., Kyoto) for 2 seconds and drained on paper towels. Dehydrated samples were rehydrated in $0.9 \%$ $\mathrm{NaCl}$ solution at $10^{\circ} \mathrm{C}$ for 5 hours.

Freezing and thawing Sample tissues were encaged in a $90-\mathrm{mm}$ petri dish and sealed with Parafilm (American National Can, USA). The dish was stored in a refrigerator at $5^{\circ} \mathrm{C}$ for $30 \mathrm{~min}$, then cooled and frozen in a freezer at $-10^{\circ}$ or $-18^{\circ} \mathrm{C}$. The temperature was measured by a copper-constantan thermocouple placed at the center of the sample. After freezing, samples were thawed for $1 \mathrm{hr}$ at room temperature $\left(25^{\circ} \mathrm{C}\right)$ until their temperature reached approximately $20^{\circ} \mathrm{C}$. Dehydrated samples after freezing were thawed and rehydrated in $0.9 \% \mathrm{NaCl}$ solution at $10^{\circ} \mathrm{C}$ for 5 hours.

Electrical properties of agricultural products The electrical properties of agricultural products were measured by a LCR meter (3523-50; Hioki, Japan) with a test fixture (16047C; Hewlett-Packard Japan) (Ohnishi et al., 2002). Two electrodes of platinum wire $(0.3 \mathrm{~mm}$ in diameter $)$ connected to the test fixture were plunged into the sample (5 $\mathrm{mm}$ deep) in the direction perpendicular to the long axis of the cylindrical sample. The distance between the two electrodes was $30 \mathrm{~mm}$. The complex impedance $\left(Z^{\prime}=R+j X ; R\right.$, resistance; $X$, reactance) of the sample was measured over a frequency range from $50 \mathrm{~Hz}$ to $1 \mathrm{MHz}$ at 0.1 volt.

When the sample has a cellular structure, a plot of resistance against reactance shows a characteristic arc called the Cole-Cole arc (Cole, 1932; Hayden et al., 1969), which is analyzed by the method of Kato et al. (2000). The circle equation can be described as follows:

$$
(\mathrm{R}-\mathrm{a})^{2}+(\mathrm{X}-\mathrm{b})^{2}=\mathrm{r}^{2}
$$

where $\mathrm{a}$ and $\mathrm{b}$ are parameters to be optimized and $\mathrm{r}$ is the radius of the Cole-Cole arc.

This equation is transformed into a linear equation form as

$$
\mathrm{Y}=\mathrm{aX}_{1}+\mathrm{bX}_{2}+\mathrm{c}
$$

where

$$
\begin{gathered}
\mathrm{Y}=\mathrm{R}^{2}+\mathrm{X}^{2} \\
\mathrm{X}_{1}=2 \mathrm{R} \\
\mathrm{X}_{2}=2 \mathrm{X}
\end{gathered}
$$

$$
\mathrm{c}=\mathrm{r}^{2}-\mathrm{a}^{2}-\mathrm{b}^{2}
$$

And the sum of squares of residual $(\mathrm{S})$ is defined as

$$
S=\sum_{j=1}^{m}\left(Y_{j}-Y_{\text {calj }}\right)^{2}
$$

where the subscript cal denotes the calculated value. The optimal parameters for Eq. (2) were obtained by minimizing S in Eq. (7) using a least squares method with EQUATRAN-G for Windows Version 3.0 (Omega Simulation Inc, Tokyo, Japan) and the radius of the Cole-Cole arc, r, was obtained by

$$
\mathrm{r}=\left(\mathrm{a}^{2}+\mathrm{b}^{2}+\mathrm{c}\right)^{0.5}
$$

Measurement of rheological properties Rheological properties of agricultural products were determined by the vibrating reed method (Dejmek and Miyawaki, 2002; Ohnishi et al., 2002; Drake 1962; Miyawaki and Yano, 1980). Cylindrical samples were dipped in liquid paraffin (Nacalai tesque, inc., Kyoto, Japan) to prevent drying during measurement. The top end of the cylindrical sample was held by a sample holder of acrylic resin, and vibrated at a frequency from 0 to $100 \mathrm{~Hz}$ by an electromagnetic vibrator (Model PET-0A; IMV Corporation, Japan). The movement of the bottom edge at the free end of the beam was measured by a laser displacement sensor (LK-030; Keyence Corporation, Japan), and the resonance curve was analyzed. Dynamic elasticity $\left(E^{\prime}[\mathrm{N} /\right.$ $\left.\left.\mathrm{m}^{2}\right]\right)$ and dynamic viscosity $\left(\eta^{\prime}\left[\mathrm{N} \cdot \mathrm{s} / \mathrm{m}^{2}\right]\right)$ were calculated from the following equations (Nishinari et al., 1977).

$$
\begin{aligned}
& \left.E^{\prime}=\left(4 \pi^{2} \rho l^{4} / a_{0}{ }^{4} k^{2}\right) f^{2}\left\{1-3 / 8(\Delta f / f)^{2}\right\}\right\} \\
& \eta^{\prime}=\left(2 \pi \rho l^{4} / a_{0}{ }^{4} k^{2}\right) f^{2}\left\{1-3 / 8(\Delta f / f)^{2}\right\}
\end{aligned}
$$

where $f[\mathrm{~Hz}]$ is the resonance frequency, $\Delta f[\mathrm{~Hz}]$ is the width of the resonance curve at which the resonance amplitude is $1 / 2^{0.5}$ times the maximum resonance amplitude, $l[\mathrm{~cm}]$ is the length of the beam sample excluding the part held by the sample holder, $D[\mathrm{~cm}]$ is the diameter of the sample, $\rho\left[\mathrm{g} / \mathrm{cm}^{3}\right]$ is the density of the sample, $a_{0}$ is a constant for the fundamental vibration (1.875), and $k^{2}$ is the moment of inertia of the cross section around the neutral axis per cross section area $\left(D^{2} / 16\right.$ for cylindrical sample). Using a fixed condition of freezing-thawing and osmotic dehydration-rehydration measurements were repeated three times for different samples to obtain the dynamic viscoelasticity. The sample density was measured with an electric density meter (EW-200SG; Mirage Trading Inc., Japan) that measures the sample weights in air and in water. The mean density value from three samples was used for calculating viscoelasticity using Eqs. (10) and (11).

Measurement of drip after various treatments The amount of drip was determined by a centrifugation method (Miyawaki and Shimiya, 2002; Shimiya and Miyawaki, 2004). Samples were centrifuged at $2,330 \times \mathrm{g}$ for $30 \mathrm{~min}$ at $25^{\circ} \mathrm{C}$. The percent loss in weight of the sample was defined as the amount of drip. Three samples were used and the mean value was obtained. 
Observation of cell structure with optical microscope A digital microscope (VH-2450, VH-5910, Keyence, Japan) was used to obtain images of the agricultural products tissues before and after various treatments. The cylindrical sample was cut in the direction perpendicular to the long axis and the surface exposed by cutting was drained with paper towels. The surface was observed by a digital optical microscope.

Moisture contents of agricultural products The moisture content was determined by the air-oven method by drying for $17 \mathrm{~h}$ at $105^{\circ} \mathrm{C}$. Three samples were used and the mean value was obtained.

\section{Results and Discussion}

Effect of osmotic dehydration on rheological properties of plant tissues Table 1 shows the rheological properties of three agricultural products, carrot, broccoli and potato, before and after various treatments. The dynamic elasticity and viscosity of the untreated agricultural products decreased by more than one order of magnitude after freezing-thawing. This mainly reflects the plasma membrane injury through ice crystal formation followed by the loss of turgor pressure, which is the major cause of softening after freezing-thawing (Ohnishi et al., 2003; Ohnishi et al., 2004). In the freezing-thawing process, the difference in freezing temperature, $-10^{\circ} \mathrm{C}$ or $-18^{\circ} \mathrm{C}$, did not affect the degree of cell tissue softening after thawing. Most water in plant tissue freezes when the temperature of the sample falls below $-5^{\circ} \mathrm{C}$ (Ohnishi et al., 2003). When a plant tissue is stored at $-10^{\circ} \mathrm{C}$, the cell plasma membrane is thought to be injured by ice crystal formation as well as when stored at $-18^{\circ} \mathrm{C}$. Consequently, it is necessary to store above $-5^{\circ} \mathrm{C}$ or to reduce the freezable water content to limit cell plasma membrane injury.

Table 1 also shows the rheological properties of plant tissues after osmotic dehydration and rehydration.
After osmotic dehydration, the water contents of the cell tissues were approximately 50\%. In carrot and broccoli, the extent of decrease in the dynamic elasticity and viscosity after dehydration-rehydration was smaller than after freezing-thawing. In particular, the dynamic elasticity of broccoli remained above the $80 \%$ level of fresh tissue. These results show that osmotic dehydrationrehydration is relatively mild on the cell structure for carrot and broccoli tissue. In potato, however, rheological properties decreased to the same level of those after freezing-thawing, showing that this sample is susceptible to osmotic stress.

Then, we measured the rheological properties of osmotically dehydrated samples after freezing-thawingrehydration. Carrot and broccoli tissues showed higher rheological properties than those after freezing-thawing without treatment, showing that the osmotic treatment prevented the tissue softening after freezing-thawing by reducing freezable water content in the cell tissue. In this process, samples frozen at $-10^{\circ} \mathrm{C}$ showed the higher rheological properties than those frozen at $-18^{\circ} \mathrm{C}$.

Comparison of cell plasma membrane injury after various treatments by electrical measurement The osmotic dehydration was assumed to reduce the freezable water content in the plant tissue to decrease the cell structure injury, especially on the cell plasma membrane. To confirm this, we measured the electrical properties of tissues to estimate the state of the cell plasma membrane. Reactance $(\mathrm{X})$ and resistance $(\mathrm{R})$ of the cell tissues were measured over a frequency range from $50 \mathrm{~Hz}$ to $1 \mathrm{MHz}$ before and after various treatments to obtain the ColeCole plots (Cole, 1932) shown in Figs. 1-3. The fresh plant tissue that has intact cell plasma membrane showed a regular Cole-Cole arc. This arc disappeared after freezing-thawing because the cell plasma membrane was destroyed by ice crystal formation and the confinement

Table 1. Comparison of rheological properties of agricultural products between raw sample and after various processes.

\begin{tabular}{|c|c|c|c|c|c|c|c|}
\hline & & Raw & $\begin{array}{c}\text { Freezing }\left(-10^{\circ} \mathrm{C}\right)- \\
\text { Thawing }\end{array}$ & $\begin{array}{c}\text { Freezing }\left(-18^{\circ} \mathrm{C}\right)- \\
\text { Thawing }\end{array}$ & $\begin{array}{l}\text { Dehydration- } \\
\text { Rehydration }\end{array}$ & $\begin{array}{c}\text { Dehydration- } \\
\text { Freezing }\left(-10^{\circ} \mathrm{C}\right)- \\
\text { Rehydration } \\
\end{array}$ & $\begin{array}{c}\text { Dehydration- } \\
\text { Freezing }\left(-18^{\circ} \mathrm{C}\right)- \\
\text { Rehydration } \\
\end{array}$ \\
\hline \multirow{2}{*}{ Carrot } & $\begin{array}{c}\text { Elasticity } \\
{\left[\times 10^{5} \mathrm{~N} / \mathrm{m}^{2}\right]} \\
( \pm \text { S.E. })^{\mathrm{a}}\end{array}$ & $\begin{array}{r}66.48 \\
(12.43)\end{array}$ & $\begin{array}{r}5.08 \\
(0.18)\end{array}$ & $\begin{array}{r}6.22 \\
(1.15)\end{array}$ & $\begin{array}{l}21.31 \\
(4.94)\end{array}$ & $\begin{array}{l}20.84 \\
(4.48)\end{array}$ & $\begin{array}{r}11.59 \\
(3.62)\end{array}$ \\
\hline & $\begin{array}{c}\text { Viscosity } \\
{\left[\mathrm{x} 10^{2} \mathrm{~N} \cdot \mathrm{s} / \mathrm{m}^{2}\right]} \\
( \pm \text { S.E. })^{\mathrm{a}}\end{array}$ & $\begin{array}{r}21.89 \\
(1.76)\end{array}$ & $\begin{array}{r}2.98 \\
(0.33)\end{array}$ & $\begin{array}{r}3.63 \\
(1.05)\end{array}$ & $\begin{array}{r}8.00 \\
(1.46)\end{array}$ & $\begin{array}{r}11.69 \\
(2.92)\end{array}$ & $\begin{array}{r}6.42 \\
(0.58)\end{array}$ \\
\hline \multirow{2}{*}{ Broccoli } & $\begin{array}{c}\text { Elasticity } \\
{\left[\mathrm{x} 10^{5} \mathrm{~N} / \mathrm{m}^{2}\right]} \\
( \pm \mathrm{S} . \mathrm{E} .)^{\mathrm{a}}{ }^{2}\end{array}$ & $\begin{array}{r}42.04 \\
(11.98)\end{array}$ & $\begin{array}{r}2.20 \\
(0.50)\end{array}$ & $\begin{array}{r}2.27 \\
(1.35)\end{array}$ & $\begin{array}{l}34.85 \\
(3.07)\end{array}$ & $\begin{array}{r}7.81 \\
(1.94)\end{array}$ & $\begin{array}{r}3.20 \\
(0.88)\end{array}$ \\
\hline & $\begin{array}{l}\text { Viscosity } \\
{\left[\mathrm{x} 10^{2} \mathrm{~N} \cdot \mathrm{s} / \mathrm{m}^{2}\right]} \\
( \pm \text { S.E. })^{\mathrm{a}}\end{array}$ & $\begin{array}{l}25.03 \\
(5.54)\end{array}$ & $\begin{array}{r}2.62 \\
(0.29)\end{array}$ & $\begin{array}{r}2.75 \\
(0.76)\end{array}$ & $\begin{array}{l}15.48 \\
(2.12)\end{array}$ & $\begin{array}{r}5.25 \\
(0.60)\end{array}$ & $\begin{array}{r}4.54 \\
(1.23)\end{array}$ \\
\hline \multirow{2}{*}{ Potato } & $\begin{array}{c}\text { Elasticity } \\
{\left[\times 10^{5} \mathrm{~N} / \mathrm{m}^{2}\right]} \\
( \pm \text { S.E. })^{\mathrm{a}}\end{array}$ & $\begin{array}{r}91.46 \\
(13.64)\end{array}$ & $\begin{array}{r}0.58 \\
(0.11)\end{array}$ & $\begin{array}{r}0.51 \\
(0.13)\end{array}$ & $\begin{array}{r}0.44 \\
(0.17)\end{array}$ & $\begin{array}{r}0.58 \\
(0.10)\end{array}$ & $\begin{array}{r}0.49 \\
(0.19)\end{array}$ \\
\hline & $\begin{array}{c}\text { Viscosity } \\
{\left[\mathrm{x} 10^{2} \mathrm{~N} \cdot \mathrm{s} / \mathrm{m}^{2}\right]} \\
( \pm \text { S.E. })^{\mathrm{a}}\end{array}$ & $\begin{array}{l}40.09 \\
(5.37)\end{array}$ & $\begin{array}{r}0.79 \\
(0.02)\end{array}$ & $\begin{array}{r}0.78 \\
(0.17)\end{array}$ & $\begin{array}{r}0.62 \\
(0.23)\end{array}$ & $\begin{array}{r}0.73 \\
(0.25)\end{array}$ & $\begin{array}{r}0.78 \\
(0.07)\end{array}$ \\
\hline
\end{tabular}

a: Each value is mean $( \pm$ S.E. $)$ for 3 samples. 


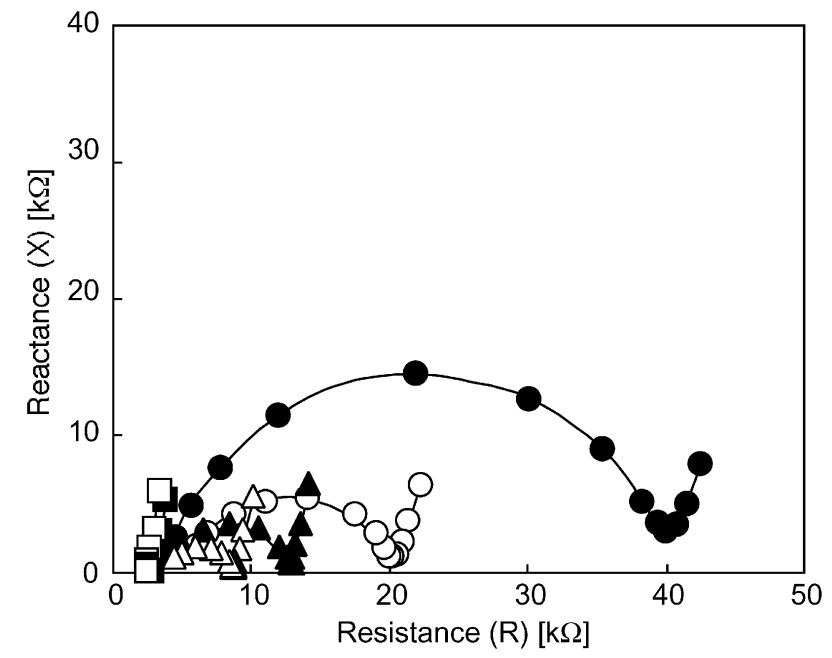

Fig. 1. Electrical properties of carrot (Cole-Cole plot) before and after various processes. $\bigcirc$, fresh tissues; $\bigcirc$, after osmotic dehydration-rehydration; $\boldsymbol{\Lambda}$, after osmotic dehydration-freezing $\left(-10^{\circ} \mathrm{C}\right)$-rehydration (thawing); $\triangle$, after osmotic dehydrationfreezing $\left(-18^{\circ} \mathrm{C}\right)$-rehydration (thawing); $\boldsymbol{\square}$, after freezing $\left(-10^{\circ} \mathrm{C}\right)$ thawing; $\square$, after freezing $\left(-18^{\circ} \mathrm{C}\right)$-thawing.

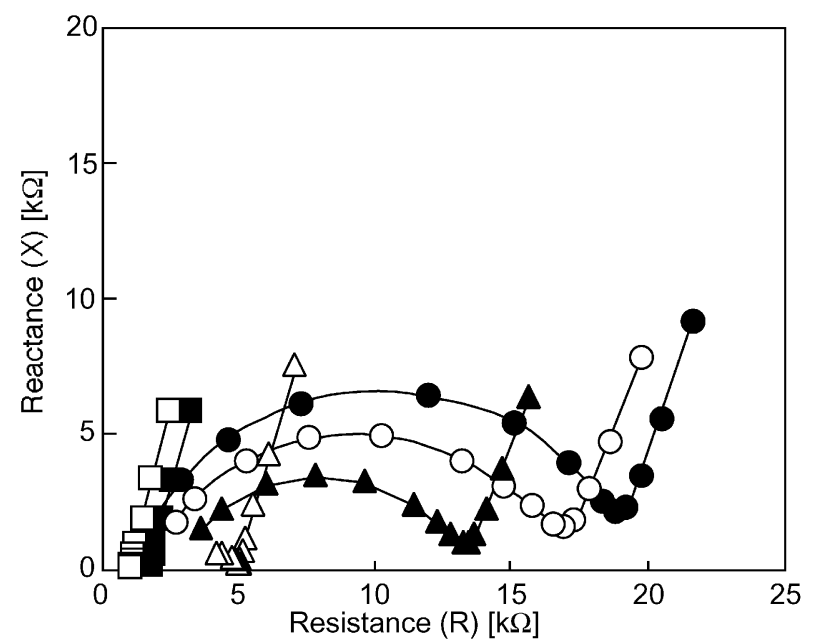

Fig. 2. Electrical properties of broccoli (Cole-Cole plot) before and after various processes. $\bigcirc$, fresh tissues; $\bigcirc$, after osmotic dehydration-rehydration; $\boldsymbol{\Lambda}$, after osmotic dehydration-freezing $\left(-10^{\circ} \mathrm{C}\right)$-rehydration (thawing); $\triangle$, after osmotic dehydrationfreezing $\left(-18^{\circ} \mathrm{C}\right)$-rehydration (thawing); $\boldsymbol{\square}$, after freezing $\left(-10^{\circ} \mathrm{C}\right)$ thawing; $\square$, after freezing $\left(-18^{\circ} \mathrm{C}\right)$-thawing.

structure of the cell structure was lost (Dejmek and Miyawaki, 2002). In carrot and broccoli tissues after dehydration-rehydration, the Cole-Cole arcs were observed though they became smaller than those of fresh samples (Figs. 1 and 2). This shows that the plasma membrane injury caused by the osmotic dehydration was less than that caused by freezing such that part of the cell membrane structure still remained intact after the treatment. Furthermore, the Cole-Cole arcs of osmotically dehydrated samples after freezing-thawing-rehydration did not disappear, though they became smaller than those after dehydration-rehydration. These results show that

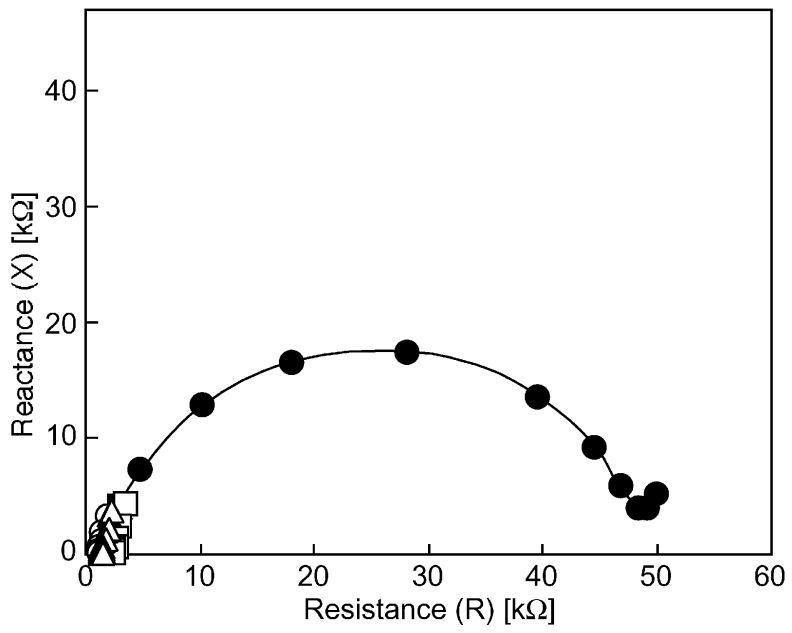

Fig. 3. Electrical properties of potato (Cole-Cole plot) before and after various processes. - Fresh tissues; $\bigcirc$, after osmotic dehydration-rehydration; $\boldsymbol{\Delta}$, after osmotic dehydration-freezing $\left(-10^{\circ} \mathrm{C}\right)$-rehydration (thawing); $\triangle$, after osmotic dehydrationfreezing $\left(-18^{\circ} \mathrm{C}\right)$-rehydration (thawing); $\boldsymbol{\square}$, after freezing $\left(-10^{\circ} \mathrm{C}\right)$ thawing; $\square$, after freezing $\left(-18^{\circ} \mathrm{C}\right)$-thawing.

part of the cell plasma membrane structure was protected from freezing injury. On the other hand, the Cole-Cole arc completely disappeared for the potato sample after dehydration-rehydration as well as after freezing-thawing, showing the weakness of the potato membrane (Fig. 3). This corresponds well to the fact that the potato tissue showed no difference in rheological properties for the samples after freezing-thawing and osmotic dehydration-rehydration treatment (Table 1).

The electrical and rheological properties were compared for carrot and broccoli (Figs. 4 and 5). The radius of the Cole-Cole arc shows good correlation with the rheological properties of the carrot tissue (elasticity, $\mathrm{r}=$ 0.953; viscosity, $r=0.895$ ) and broccoli tissue (elasticity, $r$ $=0.980$; viscosity, $r=0.953$ ). These results suggest that the smaller reduction in rheological values after freezing observed for the osmotically dehydrated sample as compared with the untreated sample reflects less injury of the plasma membrane.

Cell structure after various treatments To evaluate the condition of the plasma membrane more directly, we measured the amount of drip after various treatments for carrot, broccoli and potato (Table 2). No drip was observed from the raw tissue sample by centrifugation at $2,330 \times \mathrm{g}$ for $30 \mathrm{~min}$ because the plasma membrane blocked free movement of water in the cell. In the untreated sample after freezing-thawing, $1 / 3$ to $1 / 2$ of the water was lost from the tissue by drip, showing the serious cell plasma membrane injury by the ice crystal formation. In carrot and broccoli, the osmotic dehydration-rehydration treatment scarcely affected the amount of drip. The osmotically dehydrated sample showed a smaller amount of drip after freezing-thawing-rehydration. On the other hand, a substantial amount of drip flowed out from potato tissue after all the treatments.

The cell tissue structure of carrot, broccoli and potato 
were observed with an optical microscope. In the raw tissue (Figs. 6a, 7a and 8a), the combined structure of cell wall and cell plasma membrane was clearly observed, while in the untreated sample after freezing $\left(-18^{\circ} \mathrm{C}\right)$ thawing, the tissue surface was covered with the drip flowing out from the cell, suggesting a damaged cell plasma membrane (Figs. 6b, 7b and 8b). In the osmotically dehydrated-rehydrated sample of carrot and broc-

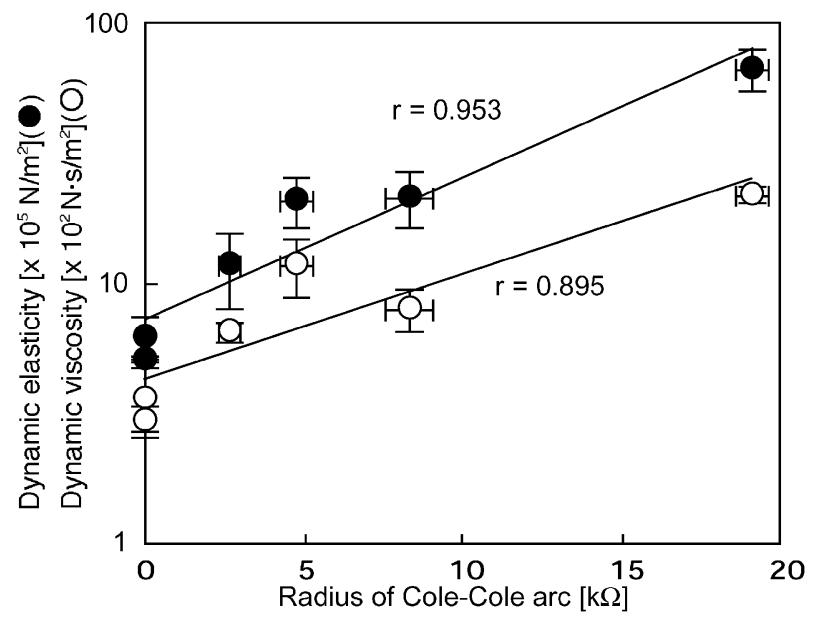

Fig. 4. Relation between rheological properties (radius of ColeCole arc) and electrical properties of carrot tissues. 0 , dynamic elasticity; $\bigcirc$, dynamic viscosity.

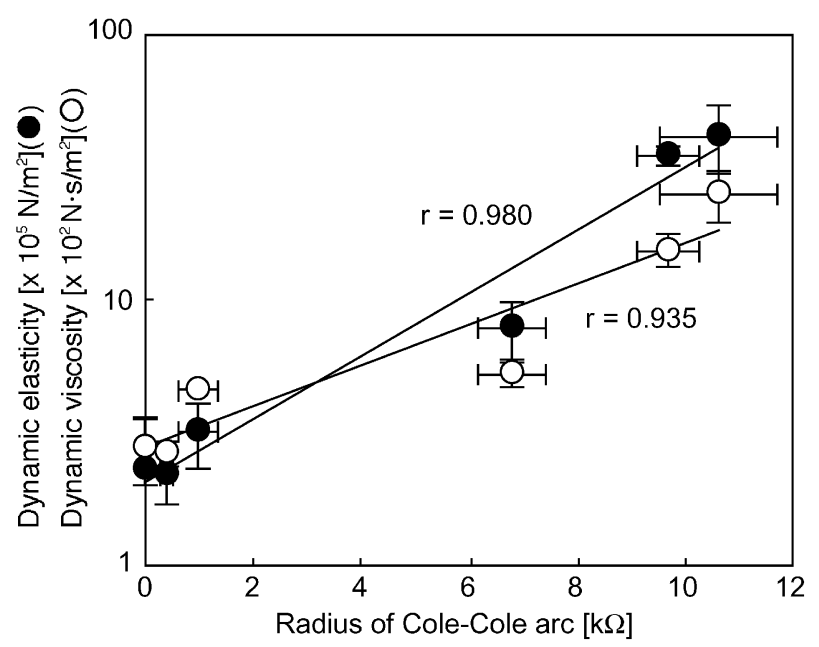

Fig. 5. Relation between rheological properties (radius of ColeCole arc) and electrical properties of broccoli tissues. $\mathbf{0}$, dynamic elasticity; $\bigcirc$, dynamic viscosity. coli, the cell structure was apparently intact with no drip observed (Figs. 6c and 7c). In particular, the broccoli tissue after dehydration-rehydration seemed almost the same as fresh tissue. In the osmotically dehydrated sample of carrot and broccoli after freezing-thawing-

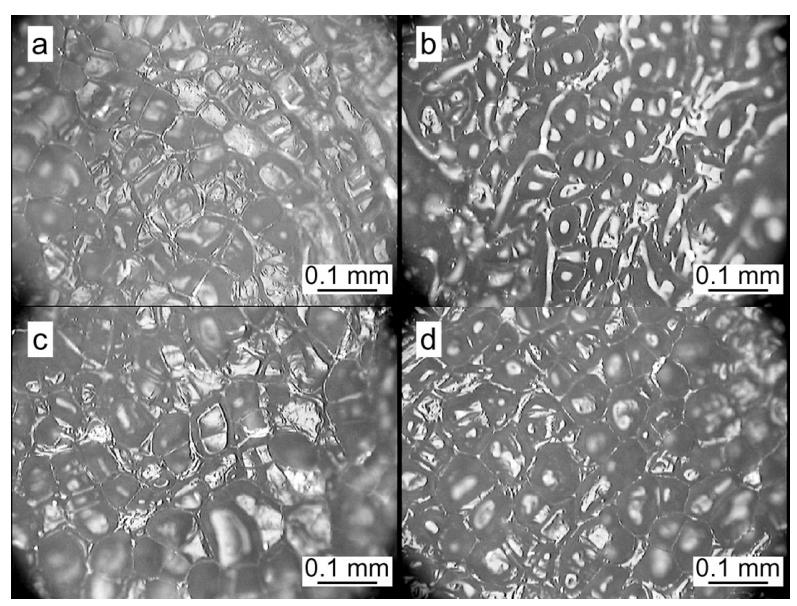

Fig. 6. Digital microscope image of carrot tissue surface before and after various treatments. a, fresh tissues; b, after freezing $\left(-18^{\circ} \mathrm{C}\right)$-thawing; $\mathrm{c}$, after osmotic dehydration-rehydration; $\mathrm{d}$, after osmotic dehydration-freezing $\left(-18^{\circ} \mathrm{C}\right)$-rehydration (thawing).

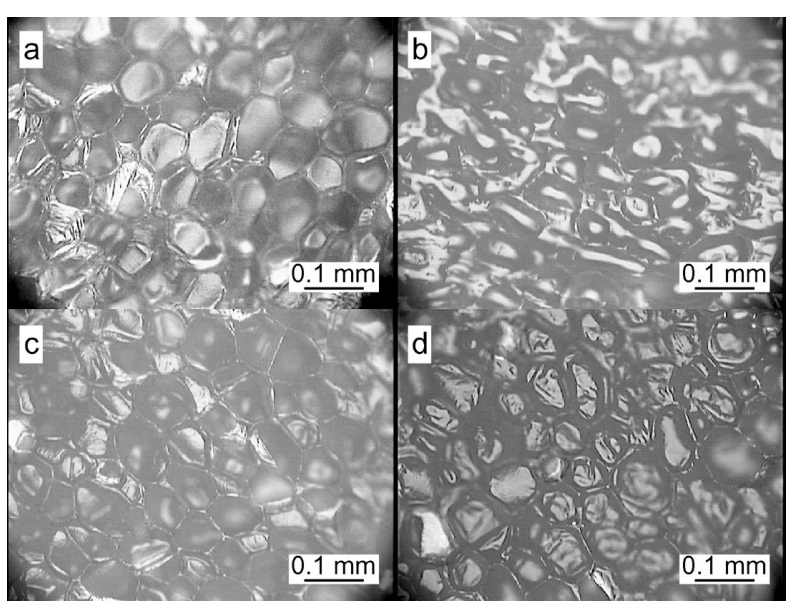

Fig. 7. Digital microscope image of broccoli tissue surface before and after various treatments. a, fresh tissues; $b$, after freezing $\left(-18^{\circ} \mathrm{C}\right)$-thawing; c, after osmotic dehydration-rehydration; $\mathrm{d}$, after osmotic dehydration-freezing $\left(-18^{\circ} \mathrm{C}\right)$-rehydration (thawing).

Table 2. Amount of drip after various treatments (\% \pm S.E. $)^{\text {a. }}$.

\begin{tabular}{lrrr}
\hline & \multicolumn{1}{c}{ Carrot } & \multicolumn{1}{c}{ Broccoli } & \multicolumn{1}{c}{ Potato } \\
\hline \hline Fresh $($ Raw $)$ & $0.07(0.00)$ & $0.02(0.08)$ & $5.39(0.08)$ \\
\hline Freezing $\left(-10^{\circ} \mathrm{C}\right)$-Thawing & $24.68(3.94)$ & $30.57(6.23)$ & $51.27(3.90)$ \\
\hline Freezing $\left(-18^{\circ} \mathrm{C}\right)$-Thawing & $30.91(0.34)$ & $46.56(4.05)$ & $57.27(4.25)$ \\
\hline Dehydration-Rehydration & $0.67(0.27)$ & $8.49(0.69)$ & $25.40(1.10)$ \\
\hline Dehydration-Freezing $\left(-10^{\circ} \mathrm{C}\right)$-Rehydration & $3.97(0.62)$ & $15.96(2.52)$ & $30.97(2.00)$ \\
\hline Dehydration-Freezing $\left(-18^{\circ} \mathrm{C}\right)-$-Rehydration & $7.47(0.87)$ & $20.90(2.47)$ & $34.97(1.87)$ \\
\hline
\end{tabular}

a: Each value is mean $( \pm$ S.E. $)$ for 3 samples. 


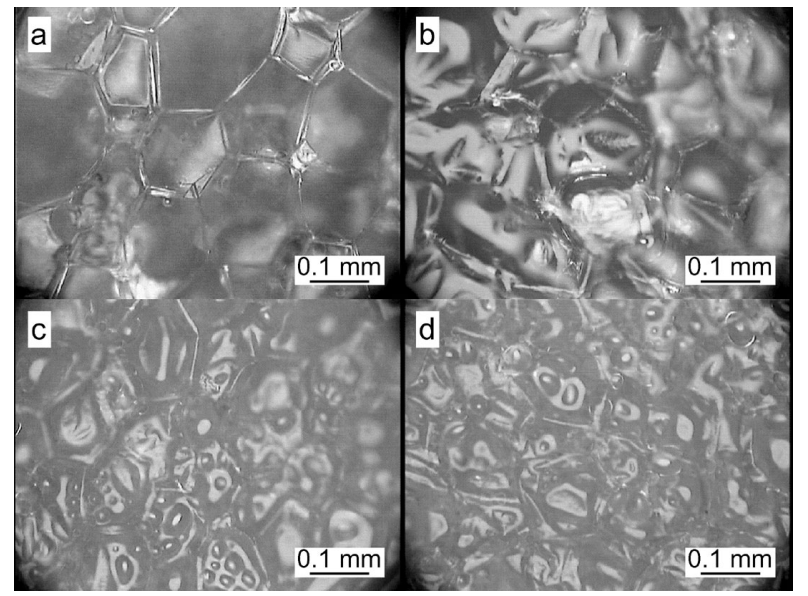

Fig. 8. Digital microscope image of potato tissue surface before and after various treatments. a, fresh tissues; b, after freezing $\left(-18^{\circ} \mathrm{C}\right)$-thawing; $\mathrm{c}$, after osmotic dehydration-rehydration; d, after osmotic dehydration-freezing $\left(-18^{\circ} \mathrm{C}\right)$-rehydration (thawing).

rehydration (Figs. $6 \mathrm{~d}$ and $7 \mathrm{~d}$ ), the apparent cell structure seemed much better than the untreated sample after freezing-thawing (Figs. $6 \mathrm{~b}$ and $7 \mathrm{~b}$ ), although a shrinkage of the cell wall was observed. On the contrary, the potato sample was highly susceptible to osmotic dehydration and osmotic dehydrofreezing (Figs. 8c, d) as compared with carrot and broccoli. The potato cell is much larger than the cells of the other vegetables (Figs. 6a, 7a, 8a). In addition, the fiber content of the potato is $1.1 \%$ (Kagawa, 1998), which is substantially less than broccoli $(4.8 \%)$ and carrot $(2.4 \%)$. Although the detailed mechanism is still not clear, these differences might explain the difference in cell susceptibility to osmotic and freezing stress observed among the samples.

\section{Conclusions}

Osmotic dehydrofreezing was effective in reducing the softening after freezing-thawing for carrot and broccoli samples but was not effective for the potato sample. For carrot and broccoli, the rheological properties showed good correlations with the radius of the Cole-Cole arc as an index of the intactness of the plasma membrane. For these samples, the amount of drip after freezing-thawing was less than that for the osmotically dehydrated sample. Optical observation under a microscope showed a much better cell structure after freezing-thawing for the osmotic dehydrated sample than the untreated sample. Osmotic dehydrofreezing is suggested to prevent freezing injury of the cell structure by reducing the amount of freezable water that exists intracellularly and extracellularly.

\section{References}

Biswal, R.N., Bozorgmehr, K., Tompkins, F.D. and Liu, X. (1991). Osmotic concentration of green beans prior to freezing. J. Food Sci., 56, 1008-1012.

Bolin, H.R. and Huxsoll, C.C. (1993). Partial Drying of cut pears to improve freeze/thaw texture J. Food Sci., 48, 202-205.
Burke, M.J., Gusta, L.V., Quamme, H.A., Weiser, C.J. and Li, P.H. (1976). Freezing and injury in plants. Ann. Rev. Plant Physiol., $27,507-528$.

Cole, K.S. (1932). Electric phase angle of cell membranes. J. Gen. Physiol., 15, 641-649.

Dejmek, P. and Miyawaki O. (2002). Relationship between the electrical and Rheological Properties of potato tuber tissue after various forms of processing. Biosci. Biotechnol. Biochem., 66, 1218-1223.

Drake, B. (1962). Automatic recording of vibrational properties of foodstuffs. J. Food Sci., 27, 182-188.

Forni E., Torreggiani, K., Crivelli, G., Maestrella, A., Bertolo, G. and Santelli, F. (1990). Influence of osmosis time on the quality of dehydrofrozen kiwi fruit. Acta Hort., 282, 425-434.

Garrote, R.L. and Bertone, R.A. (1989). Osmotic concentration at low temperature of frozen strawberry halves. Effect of glycerol, glucose and sucrose solutions on exudate loss during thawing. Lebensm.-Wiss. u.-Technol., 22, 264-267.

Hayden, R.I., Moyse, C.A., Calder, F.W., Crawford, D.P. and Fenson, D.S. (1969). Electrical impedance studies on potato and alfalfa tissue. J. Exper. Botany, 20, 177-200.

Howard, L.B. and Campbell, H. (1946). Dehydrofreezing- a new way of preserving food. Food Inds. 18, 674-676.

Kagawa, Y. (1998). "Standard tables of food composition in Japan" (in Japanese) ed. by Y. Kagawa. Kagawa Nutrition University's Publishing Division, Tokyo, Japan.

Kamewada, M. (1997). Kansousyokuhin no seizou no jissai (in Japanese). In "Kansousyokuhin no kiso to ouyou" ed. by Kamewada, M., Hayashi H. and Tutida, S., Saiwaisyobo, Tokyo, Japan, pp. 111-118 (in Japanese).

Kato, K., Sakaguchi, M., Ooi, Y., Maruo, S. and Toyoda, K. (2000). Measurement of the freshness of fish by impedance spectroscopy (part 1). J. Japanese Soc. Agric. Machinery, 62 (3), 76-83 (in Japanese).

Lazar, M.E., Chapin, E.O. and Smith, G.S. (1961). Dehydrofrozen apples: recent developments in processing methods. Food Technol., 14, 32-36.

Miyawaki, O. and Yano, T. (1980). Physical properties of agricultural products (in Japanese). In "Physical properties of food vol. 6" ed. by Y. Yamano. Shokuhin Shizai Kenkyu Kai, Tokyo, Japan, pp. 115-129.

Miyawaki, O. and Shimiya, Y. (2002). Freezing-thawing dehydration of food waste. Kagaku Kogaku Ronbunshu, 28, 618-620 (in Japanese).

Shimiya, Y. and Miyawaki, O. (2004). Freezing-thawing pretreatment for dehydration of food waste. Japan J Food Eng., 5, 153162 (in Japanese).

Moy, J.H., Lau, N.B.H. and Dollar, A.M. (1987). Effects of sucrose and acids on osmovac-dehydration of tropical fruits. J. Food Process. Preserve., 2, 131-135.

Moyano, P.C., Vega, R.E., Bunger, A., Garreton, J. and Osorio, F.A. (2002). Effect of combined processes of osmotic dehydration and freezing on papaya preservation. Food Sci. Tech. Inst., 8, 295-301.

Nishinari, K., Kuji, K., Karaki, Y. and Koide, S. (1977). Transverse vibrations of viscoelastic cylinders. Japanese J. Appl. Phys., 16, 19-27.

Ohnishi, S., Fujii, T. and Miyawaki, O. (2002). Electrical and rheological analysis of freezing injury of agricultural products. Int. J. Food Prop., 5, 317-332.

Ohnishi, S., Fujii, T. and Miyawaki, O. (2003). Freezing injury and rheological properties of agricultural products. Food Sci. Technol. Res., 9, 367-371.

Ohnishi, S., Shimiya, Y. and Miyawaki, O. (2004) Effect of freezing on electrical and rheological properties of food materials. Food Sci. Technol. Res., 10, 453-459.

Ponting, J.D., Watters, G.G., Forrey, R.R., Jackson, R. and Stanley, 
W.L. (1966). Osmotic dehydration of fruits. Food Technol., 20, 125-128.

Steponkus, P.L. (1984). Role of plasma membrane in freezing injury and cold acclimation. Ann. Rev. Plant Physiol., 35, 543584.

Talburt, W.F. and Legault, R.R. (1950). Dehydrofrozen peas. Food Technol., 4, 286-291.

Talburt, W.F., Walker, L.H. and Powers, M.J. (1950). Dehydrofrozen apples. Food Technol., 4, 496-498.

Talens, P., Escriche, I., MartÍnez-Navarrete, N. and Chiralt, A.
(2003). Influence of osmotic dehydration and freezing on the volatile profile of kiwi fruit. Food Res. Int., 36, 635-642.

Tregunno N.B. and Goff, H.D. (1996). Osmodehydrofreezing of apple: structural and textural effects. Food Res. Int., 29, 471479.

Virgin, H. (1955). A new method for the determination of the turgor of plant tissues. Physiol. Plant., 8, 954-962.

Webb, M.S., Uemura, M. and Steponkus, P.L. (1994). A comparison of freezing injury in oat and rye: two cereals at the extremes of freezing tolerance. Plant Physiol., 104, 467-478. 